\title{
The Unseen Drivers of Coral Health; Coral Microbiome; The Hope for Effective Coral Restoration
}

\author{
Hala F Mohamed ${ }^{1,2 *}$, Yimin Chen ${ }^{1}$, Amro Abd-Elgawad ${ }^{1}$, \\ Rongshuo Cai ${ }^{1}$, Changan $\mathrm{Xu}^{1 * *}$
}

${ }^{1}$ Third Institute of Oceanography, Ministry of Natural Resources, 178 Daxue Road, Siming District, Xiamen 361005, People's Republic of China

${ }^{2}$ Botany \& Microbiology Department, Faculty of Science, Al Azhar University (Girls Branch), Cairo, Egypt

\begin{tabular}{|l|l|}
\hline Removed & Added \\
\hline \multicolumn{1}{|c|}{ Acknowledgments } & \multicolumn{1}{|c|}{ Acknowledgments } \\
This work was funded by The Scientific Research & \multicolumn{1}{|c|}{$\begin{array}{l}\text { This work was funded by The Scientific Research } \\
\text { Foundation of the Third Institute of Oceanography, }\end{array}$} \\
$\begin{array}{l}\text { Foundation of the Third Institute of Oceanography, } \\
\text { MNR [2020001], China APEC Foundation [HV01- }\end{array}$ & $\begin{array}{l}\text { MNR [2020002], China APEC Foundation [HV01- } \\
\text { 190101(1)], Xiamen, Marine and Fishery Development }\end{array}$ \\
$\begin{array}{l}\text { Special Foundation [19CZP011HJ08], and The Special } \\
\text { Scientific Research Fund of Public Welfare Profession of Xiamen, Marine and Fishery Development }\end{array}$ & $\begin{array}{l}\text { Special Foundation [19CZP011HJ08], and The Special } \\
\text { Scientific Research Fund of Public Welfare Profession of } \\
\text { China [201405038]. }\end{array}$ \\
\hline
\end{tabular}


Review

\title{
The Unseen Drivers of Coral Health; Coral Microbiome; The Hope for Effective Coral Restoration
}

\author{
Hala F Mohamed ${ }^{1,2 *}$, Yimin Chen ${ }^{1}$, Amro Abd-Elgawad ${ }^{1}$, \\ Rongshuo Cai ${ }^{1}$, Changan $\mathrm{Xu}^{1 * *}$ \\ ${ }^{1}$ Third Institute of Oceanography, Ministry of Natural Resources, 178 Daxue Road, Siming District, Xiamen 361005, \\ People's Republic of China \\ ${ }^{2}$ Botany \& Microbiology Department, Faculty of Science, Al Azhar University (Girls Branch), Cairo, Egypt
}

Received: 18 May 2021

Accepted: 7 August 2021

\begin{abstract}
Coral restoration is important in ocean engineering because corals play a crucial role for sustainable marine ecosystems and in global carbon cycle. Coral microbiome controls the host life and functions by occupying different coral components such as tissue, skeleton, mucus and surrounding water. They work together as a complementary community to create the circle of healthy life for coral reefs. In addition to their role in carbon, nitrogen and sulfur cycling, metabolism and defence, their pattern of abundance and diversity shapes coral resilience and adaptation to the changing environment. As coral reefs are facing a tremendous decline by climate change and human activities, we here review the motors shifting the pattern of natural coral microbiome, and how this microbiome shift could affect coral health or drive coral adaptation to both climate change and anthropogenic disturbances. The available coral restoration techniques and their limitations are also discussed, particularly the new arising trend of coral restoration through coral microbiome. After presenting the high value of microbial community in maintaining coral reef health, we suggest that coral restoration through their microbiome could be a self-sustaining tool in fighting worldwide coral decline and urge scientist to draw more attention toward this new approach.
\end{abstract}

Keywords: coral microbiome, restoration, metagenomic analysis, adaptation, climate change

*e-mail: hala@tio.org.cn

**e-mail: xuchangan@tio.org.cn 


\section{Introduction}

\section{Coral Reef and Carbon Capture and Sequestration}

Although Tropical coral reef represents $0.1 \%$ of the ocean but is considered one of the most biodiverse communities on the earth, harbouring one quarter of all marine life. They support human society through a range of services such as fisheries, tourism, livelihood, erosion prevention and defence against disturbed environmental changes [1]. A tremendous decline of coral reefs is caused by Climate change, which affect their function and health [2]. Elevation of carbon dioxide level associated with climate change leads to water acidification which disturbs ocean carbonate chemistry and hence tragically affect coral physiology as the rate of calcification become slower compared to the rate of carbonate dissolution, resulting in decline in coral reef structure and therefore all the community structure it harbours, most importantly, fishes [3], the coral bacterial community and coral holobiont in general [4]. For these reasons, carbon footprint is becoming a key interest for the universal community. More than $25 \%$ of anthropogenic carbon dioxide $\left(\mathrm{CO}_{2}\right)$ productions are held by the oceans [5]. Cycling of ocean carbon involves two main processes according to the type of carbon. Organic carbon is processed through photosynthesis and respiration by inhabitants like plants and algae while inorganic carbon is metabolised through calcification and dissolution of carbonate present in the water [6]. Calcification occurs in organisms like corals which act as carbon sinks with their hard skeletons made up of calcium carbonate [2]. They capture carbon and exhibit a carbon sequestration potential calculated to be up to 16.5 $\mathrm{TgCyr}^{-1}$ [7]. Both calcification and dissolution of carbonate occur in harmony.

As there is shortage of lands to plant trees, attempts have been made to use ocean surface and deep bottoms in order to introduce blue carbon mechanism which is expected to help overcome ocean acidification [8]. One of the most extensively applied method was extension of microalgal biomass which is effective in carbon fixation during photosynthesis with fast growth rate [9] as they are assessed to yield two- to ten times more biomass than some terrestrial systems per unit of land area $[10,11]$. After algae start to decay, carbon dioxide is expected to emit back to the water. Many trials have been directed towards using shellfish to sequestrate the organic carbon into calcium carbonates (oceanacidification.wordpress.com/2008/04/ 24/can-seashells-save-the-world/). In the same manner, corals can also be used to sequester organic carbon during formation of their calcium carbonate skeletons with high productivity in coastal ecosystem [8]. Thus, incorporation of coral reefs can stimulate governments and public to move forward for coral reef restoration and rehabilitation that will favour its biodiversity along with their residing capacity for fisheries. Here comes the urgent need to a continuous introduction of novel and more effective coral restoration methods which facilitate coral rehabilitation to help retaining the normal calcification rate and normalization of dissolution process to balance the carbon level in the water.

\section{Coral Microbial Community}

"Coral holobiont" refers to the microbial community associated with corals such as microalgae, viruses, bacteria, fungi and archaea [12]. Although it plays a key role in reef primary metabolism, nitrogen fixation, cycling of biological matters, and defensive roles [13] (Fig. 1); coral bacterial association has not gained much attention as coral-algal relationship which has been studied extensively over the past two decades [14].

Often, environmental disturbance like climate change leads to a deficiency in the natural microbiome and hence dysbiosis, which in turn supports the rise of opportunistic pathogens [15]. As a multifaceted microbiome, they are also known for their contribution to coral resilience through various mechanisms. They regulate coral larval attachment and metamorphosis in addition to bacterial and pathogen abundance under different conditions [16]. However, superficial spot analysis studies have been made on the factors that accomplish the perfect structure of the microbial community associated with corals [17]. Host identity is likely to play a basic role in structuring coral microbiome which differs in function and assembly pattern according to its origin [18]. However, variability among the microbial community has been reported to increase with geographical distance, which indicates that the surrounding chemical and physical parameters of the environment also influence the microbial community composition [19].

Bacteria are the most abundant as a diverse group of coral microbial communities [12]. They are found to be usually distributed in three regions of the coral reef: the sediment, water column, and coral inner (tissues and skeletons). Dividing the complex reef into these different habitats facilitate study and description of diversity, distribution, abundance in addition to the fundamental role of complex microbial communities in coral reef ecosystem. Bacteria belong to each of these habitats are believed to undergo different functioning and structured in a different distribution pattern. Here we discuss the presence of bacterial communities in different parts of the coral reef and their fundamental role in nitrogen fixation and organic matters processing, which then delivered to the reef niche [20].

We here present the support the coral microbiome provides for their host to adapt to stressful conditions such as elevated temperature and ocean acidification [21]. Not only climate change disturbances but also anthropogenic stresses have a microbial response through shifting of microbiome composition. Such a shift might lead to a dominance of macroalgal growth 
a)

b)

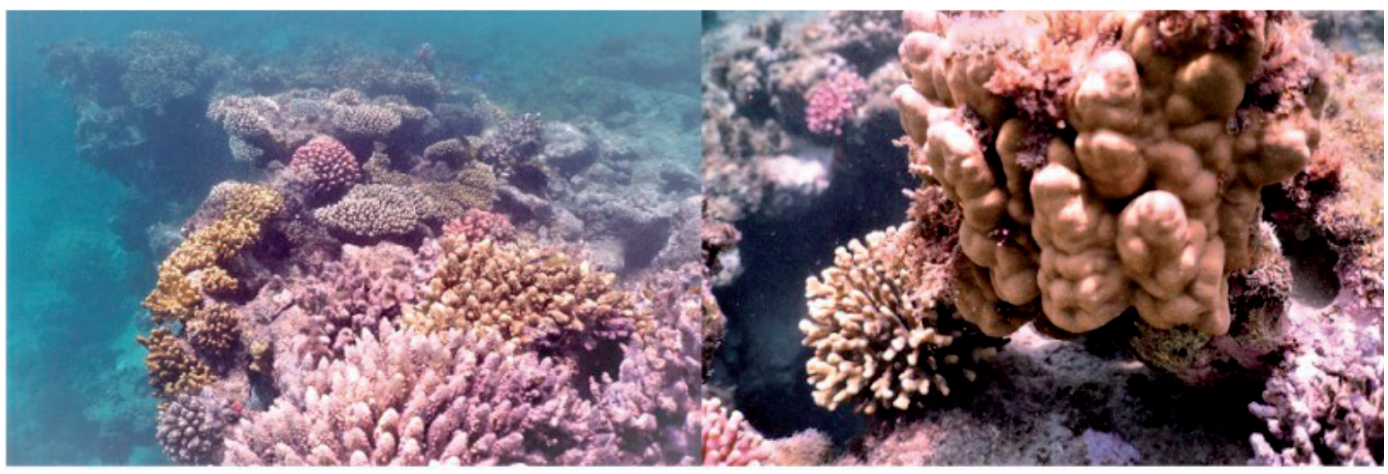

c)

d)

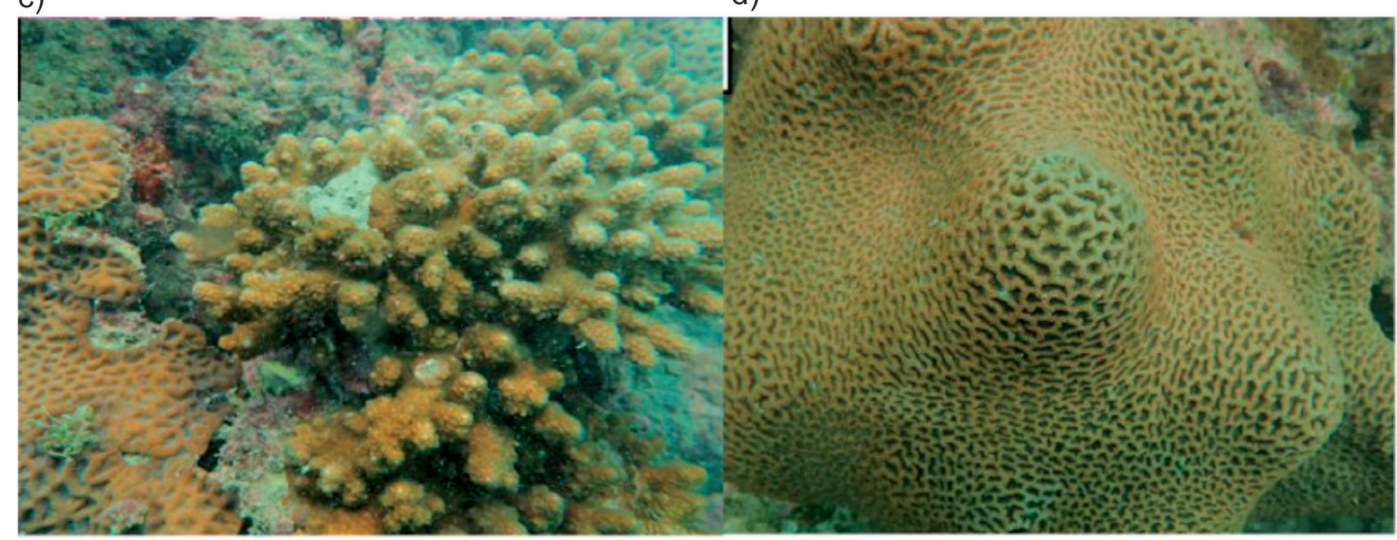

Fig. 1. Landscape images of coral reef signifying coral diversity and massive colonies. a) Hurgada, Red Sea, Egypt, b) Marsa Alam, Red Sea, Egypt; (C, D, E) Weizhou Island, China (Credit to: Amro Abd-Elgawad).

compared to corals following coral deterioration or bleaching [22]. This shift is driven and intensified by microorganisms which fastens the mortality rate of corals and accelerate the expansion of macroalgal mat in a microbialization effect of the ecosystem [23].

As the knowledge of the fundamental roles of coral microbiome in the prediction of environmental disturbance $[24,25]$, and in coral resilience expands; and the demand is growing for coral rescuing from decline, many recent approaches have been introduced for proposing coral microbiome as a rescue driver in coral restoration [15]. Here we will summarise the traditional methods of coral restoration together with their limitations in addition to the use of arising techniques using coral microbiome as a self-sustaining tool with low cost in fighting coral decline.

\section{Abundance, Diversity and Factors Structuring Microbial Composition in Coral Reef Sediment and Water}

Coral reef sediments usually harbor abundant and diverse microorganisms of similar sizes that have a fundamental role in coral reef nutrient cycling and chemical exchange [26] along with benthic phototrophs [27]. Surface sediments from the Great Barrier Reef (GBR) have reported the highest bacterial diversity in sediment surface [28]. In the Gulf of Aqaba, Red sea, microbial composition varies among different sand natures as microbiome dominance and taxonomic profile differed between silicate and carbonate sands, although bacterial diversity was similar [29]. The sand of carbonate nature is known to host higher nitrogen fixation rates than silicate sand, due to diazotrophic bacteria [30]. Moreover, studies on calcareous coral sediment indicated that bacterial populations differ in sand sampled from the shore line compared to those taken from the outer reef shelf suggesting that microbiome could be an indicator tool for water quality [31].

Metagenomic analysis of microbiome structure in coral reef samples across Heron Island collected from the water near the surface of coral species, from their sand substrate and also the surrounding water outside the reef crest demonstrated that; microbial composition related to sand and water samples outside the reef crest are dominated with an oligotrophic community such as Synechococcus and Prochlorococcus. In contrast to the community present around coral surface which is dominant in Copriotrophic species such as Alteromonas and Psuedomonas [32] (Table 1). Not only microbial composition; but also, the metabolic function of these microbial community varied. While water and sand niches show an abundance of genes linked to metabolic potentials towards primary production, interestingly, 
the coral surface shows more potential towards dynamic genes such as cell signaling, motility and chemotaxis [32]. This explains why the microbial populations present in the water column around the corals have a high tendency to work out ecological characters and shifts in the surrounding reef; due to their sensitivity towards the environment [25]. The Red Sea exhibits a continuous decrease of heterotrophic picoplankton and Synechococcus from the Southern to the Gulf of Aqaba [33], and this could result in limited colonization due to high temperature and salinity [34] Similarly, in the Gulf of Aqaba, Prochlorococcus is present in greater concentrations than Synechococcus [35].

Its obvious that studies on microbial composition associated with sediment and water columns around different coral reefs have shown consistent results. This suggests that seawater microbial community can be helpful in accurate prediction of temperature and eutrophication state. On the other hand, microbial community related to coral sediment can be governed by specific factors; for example, sand nature, depth, porosity and oxygen content, reef location, geographical distance, climate change and anthropogenic disturbances (Table 1). The role and pattern structure of microbiota are fairly variant among different locations in the coral ecosystems [32]. Coral reefs harbor a mix of microbial populations which are probably structured according to habitat composition, presence of specific coral hosts and also biogeochemical surroundings.

\section{Coral Associated Holobiont}

Corals associate with many eukaryotic and prokaryotic microorganisms. Coral holobiont is a term describing these metaassociation, composed of the animal host, symbiotic microalgae, bacteria, viruses, archaea, and fungi [14]. Here we will discuss associated microalgae and focus on bacteria as the most dominant component out of all.

\section{Diversity and Role of Microalgae Associated with Corals}

Associated microalgae allow corals to survive in a very nutrient-poor environment, and at the same time to grow and expand [36] (Fig. 2). Corals live in shallow water differ from deep sea corals in their nutritional uptake. While shallow water corals rely on photosynthetic zooxanthellae to get their needed food, deep sea corals lack photosynthesis and hence, zooxanthellae [37, 38]. This is why corals grow well only in clear water with less turbidity, to allow sun light to reach the zooxanthellate for photosynthesis. Both organisms benefit from this symbiotic relationship; corals provide protection for microalgae from the harmful surrounding microorganisms in addition to carbon dioxide and water coming from their respiration processes [37, 39]. The associated microalgae, in turn, provide corals with oxygen, glucose, glycerol and amino acid needed for their life processes. They also help corals get rid of their waste. Corals use these provided substances to produce carbohydrates, fats and proteins in addition to the synthesis of calcium carbonate $\left(\mathrm{CaCO}_{3}\right)$ needed for their skeleton building [40]. The breakdown of this symbiosis by any mean of environmental disturbances such as elevated temperatures, acidification or water pollution would lead to coral bleaching and propably death of the host.

\section{Diversity and Role of Bacterial Community Associated with Corals}

The difference between coral-associated bacterial pattern and the free-living bacteria in the water column around the corals have been thouroughly investigated [41-44]. Different studies attributed their analysed microbial composition data to a different taxonomic level which makes it difficult to report them consistently. Moreover, researchers use different parameters to measure the effect of stressors on the coral microbial community such as alpha diversity (i.e., the total number of species and their relative abundances, the Shannon and Simpson Index), beta diversity (i.e., the difference in community composition), richness (i.e., number of species), and evenness (i.e., distribution of relative abundances of species) [45].

Coral associated bacteria are the most diverse and abundant coral component out of all. They are found to be less reactive with the environmental alterations and that their population patterns are more variant compared to free-living bacterial communities [25]. Microbiome structure associated with coral tissue and mucus tends to differ according to coral species rather than site and is dissimilar to the equivalent seawater [43, 46] (Table 1). It may be mutualistic, pathogenic, or they might provide other functions related to coral health, resistance and nutrition in the reef ecosystem [47] (Fig. 2). Sometimes, they also contribute to coral diseases. Gammaproteobacteria is the most common coral- associated bacterial class, however, still considerable differences existed on species level [48, 49]. The abundance of bacterial species is highly linked to a few very abundant species and many rare species [50]. In the Red Sea, corals harbour a few abundant bacteria, however, they are species specific supporting the hypothesis of core microbiome [51]. Endozoicomonas is a core microbiome member for several corals globally suggesting that coral associated bacteria might be linked to coral reproductive metabolism [13].

Though minor differences existed among coral compartments such as skeleton, tissue and mucus, bacterial diversity was similar. Coral mucus is considered the interface between the host and the surrounding environment, so, it tends to be more likely to get affected by environmental changes [52]. Mucus in Fungia granulosa coral harbors more diverse microbiota in the natural environment compared to the aquarium [53] suggesting a functional role of 


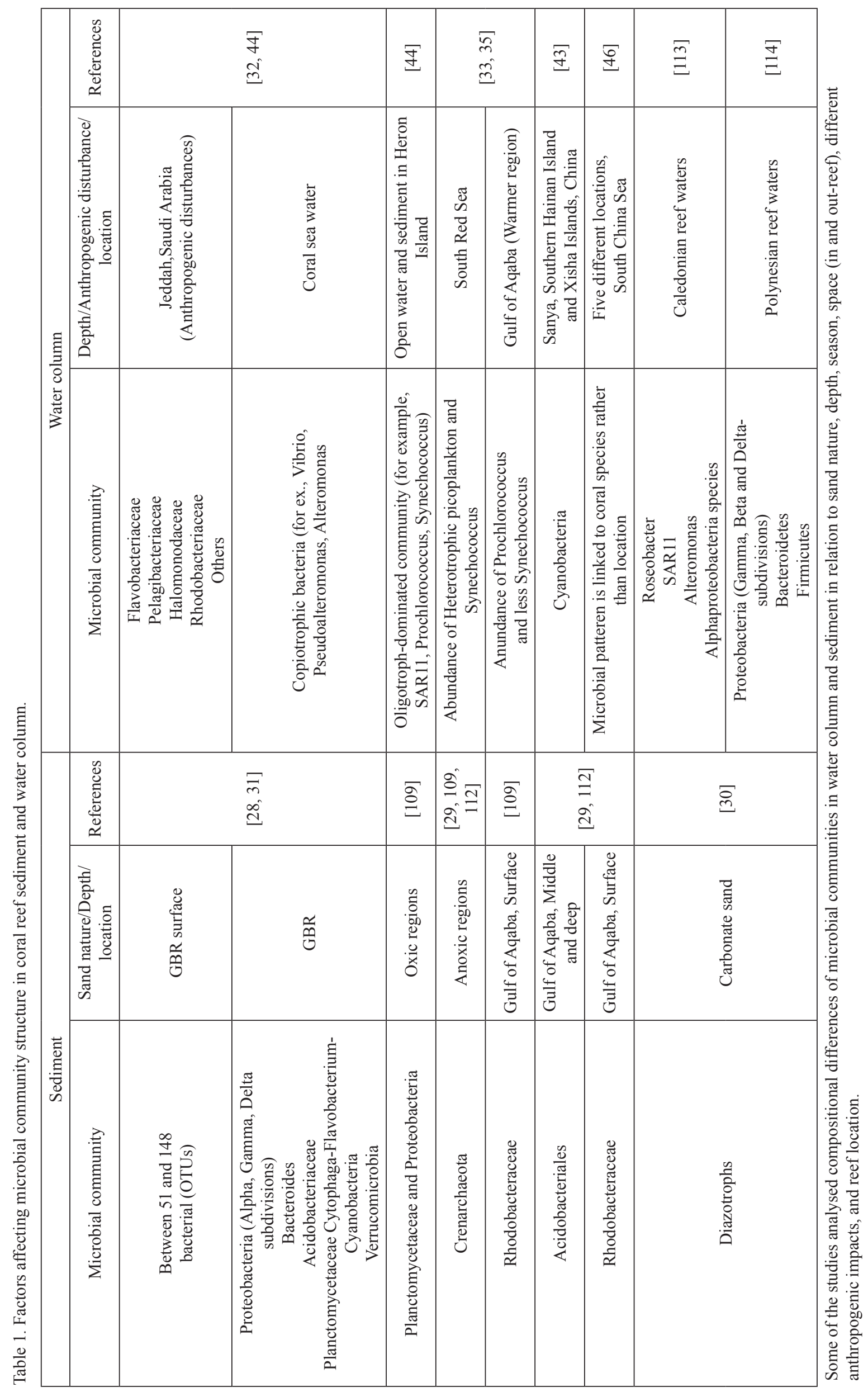




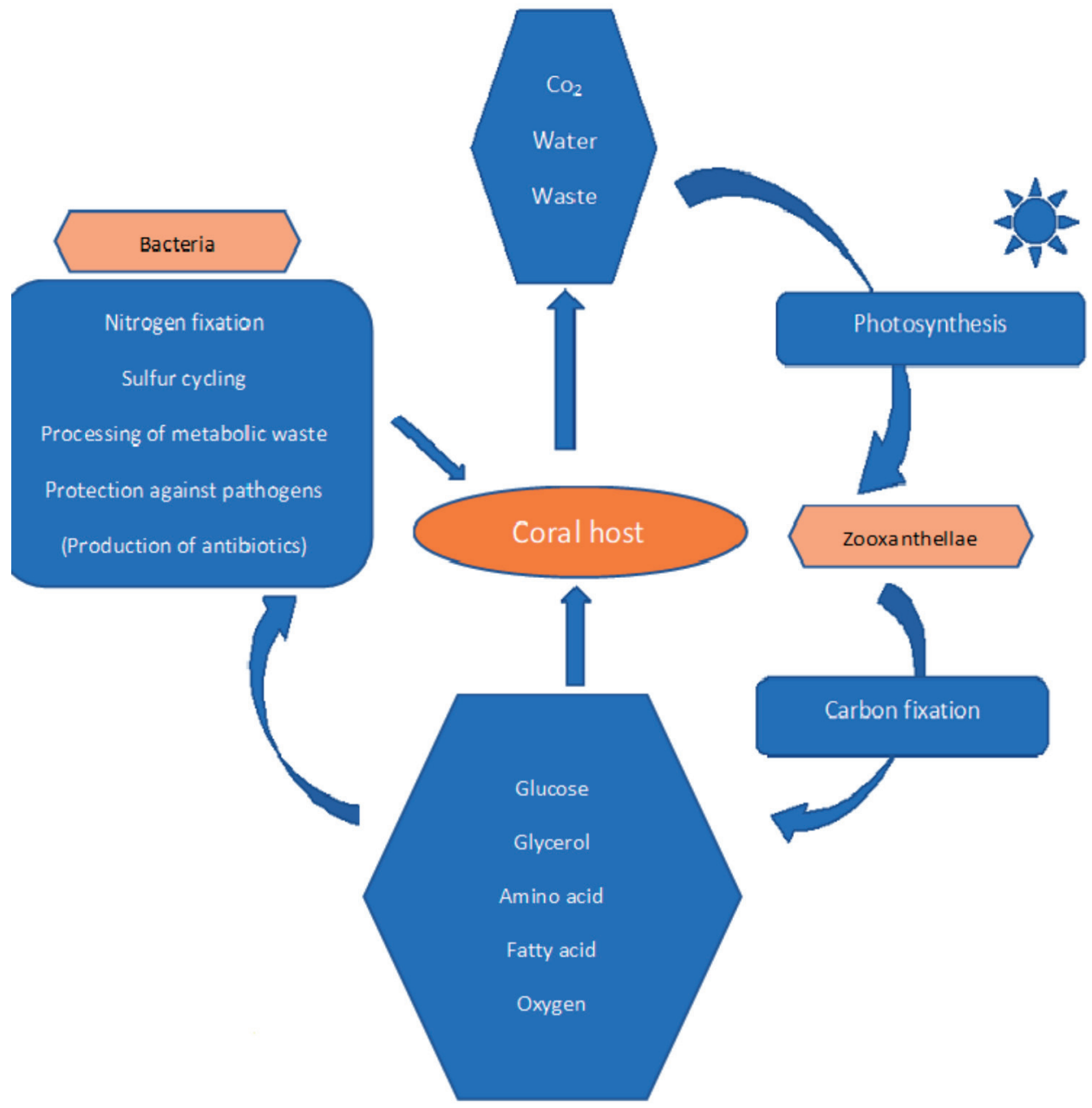

Fig. 2. Possible roles and relations among coral microbiome and microalgae (Zooxanthellae). Zooxanthellae and corals live in a beneficial symbiotic relationship. zooxanthellae give corals their colour as well as needed energy and nutrients. They undergo photosynthesis using the provided carbon dioxide and water by the corals and in turn, they provide corals with the nutrients needed for their life processes such as amino acids and fatty acids inaddition to sugar and oxygen needed for the production of coral skeletons made of calcium carbonate. Bacteria also play fundamental roles in coral nutrient cycling. They contribute to nitrogen and sulfur cycles and to phosphorus fixation and organic remediation, production of antibiotics and secondary metabolism. Also, they also play vital role in coral larval attachment and metamorphosis.

surrounding water bacteria and microbe-microbe interaction in structuring the microbial composition of coral mucus [34]. Also, Gammaproteobacteria has been reported to show higher abundance in coral mucus and tissue [43]. These results are in consistence with those from [52] conducted on Australian corals which reported that coral associated microbiome differ in their structure and abundance among coral mucus, skeleton and tissue and that the most diverse coral microbiome is present in their skeleton. They also differ in their response to environmental stress and accordingly their host. These findings explain how coral species vary in their adaptation and resilience to environmental disturbances; mainly because of their associated microbiome scattered in their different compartments. With each compartment carrying specific microbial pattern and function. Depending on the shift in these microbial association, the coral will draw a picture of the healthy, resistant or diseased colony.

\section{Factors Affecting Structure of Coral Associated Bacterial Community}

In order to understand how coral reef responds to surrounding stress, we first need to know how their associated microbiome is acting towards this stress. The stability of coral bacterial associations is governed by some intrinsic and extrinsic factors. Intrinsic factors are only biotic factors such as species-specific association. Coral bacterial communities tend to be species-specific even in far different places suggesting functions needed for coral health [54]. However, extrinsic factors could be biotic or abiotic. Extrinsic biotic factors include micro and macroorganisms such as bacteria, fungi, protozoans, ciliate and parasitic organisms [55] in addition to biofouling; by which a film of microorganisms grows on the coral surface causing tissue degradation [56]. Also, predator animals can act as vectors in disease transmission from infected to noninfected coral 
colonies [57]. Bioerosion is a mechanism by which some marine animals can cause coral decline, such as drilling, burrowing, or grazing of calcium carbonate skeleton of corals which they use for sheltering of other reef organisms [58]. Temperature, acidification, salinity, light intensity, chemical compounds, oxygen levels and nutrients, human impact, are examples of extrinsic abiotic factors affecting the structure of coral associated microbiome [34]. Temperature elevation is the most harmful abiotic stress to coral microbiome compared to other stressors. High temperature causes coral diseases due to increased abundance of Vibrio sp. [59]. Microbial pattern is known to alter with bleaching events related to high temperature but then returns to normal by disappearance of the associated impact [60]. Many studies worldwide reported a shift in coral associated microbial community following environmental stresses especially elevated temperature, acidification, increase of nutrients, in addition to anthropogenic disturbances. Gong et al. [61] sampled some abundant species from Sanya Bay reef, China, that has an average SST of $27^{\circ} \mathrm{C}$ [62] as well as Daya Bay reef, China, which has an average SST of $24^{\circ} \mathrm{C}$ along the year [63]. He revealed that the structure of microbiome differed according to thermal status as well as coral species. On the other hand, clear shift and sensitivity of microbial population in association with the CCA Neogoniolithon fosliei to $32^{\circ} \mathrm{C}$ including reduction in $\gamma$-proteobacteria (known to favor coral larval attachment and metamorphosis) and increase in Bacteroidetes has been reported [64]. Under stressful- temperature, N. fosliei also failed to perform coral larval metamorphosis hence, clear impacts on coral settlement [65]. However, it is still partially unknown how the coral microbiome responds to elevation in the SST.

Ocean acidification is also known to directly affect corals such as those with calcium carbonate skeleton [2]. For example, the $\mathrm{pH}$ reduction from 8.2 to 7.3 was found to increase the pathogenic bacteria Alteromonadaceae and Vibrionaceae in coral species Acropora eurystoma [4]. However, Cyanobacteria and Gammaproteobacteria did not have much change in their abundance. As a response to reduced water quality due to increased nutrient concentrations, some of the bacteria exhibit an increase in abundance such as Acropora hemprichii although other species, such as Endozoicomonas, show no noticeable change [66]. This is in consistence with Pinzon et al. [67] who reported interruption of microbial symbionts in coral mucus due to high level of organic carbon which favoured the growth of other specific microorganisms not supporting coral health. A direct metagenomic comparison between healthy and bleached Acropora millepora at Great Barrier Reef indicated metabolic and taxonomical shift in associated microbial community with increase in genes responsible for processing carbohydrate, protein and lipid in addition to sulfur and phosphorus [68]. Anthropogenic effects such as human pollution, oil spillage, overfishing, and sedimentation are another form of environmental

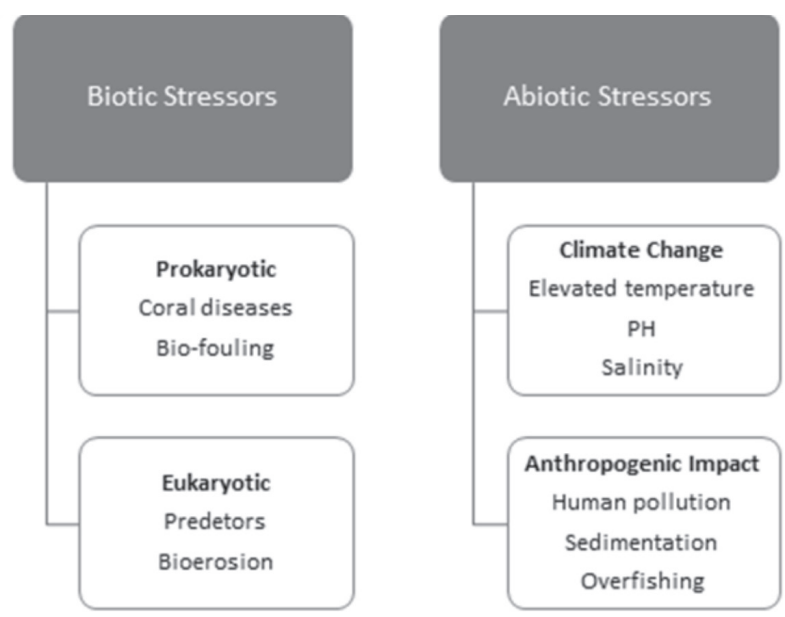

Fig. 3. Coral biotic and abiotic stressors.

disturbances that leads to shifting in coral microbiome and hence coral disease (Fig. 3).

Impact of human activities on coral microbial composition has been investigated along Jordanian coast, (Red sea) [69]. The change in microbial composition in the mucus of the coral Stylophora pistillata which was collected from five impacted sites, indicated a high diversity in the bacterial community: with Proteobacteria being the most abundant among all sites. Pathogenic Vibrio was presented with various abundances at all examined sites. In Japan, human impact on coral reef microbial structure has been assessed using metagenomic analysis at different water quality regions from Kingman to Kiritimati islands [70]. Fishing and land use were accompanied by shifts in the microbial diversity and direction towards heterotrophy. In addition to the presence of pathogens at the most populated area of Kiritimati island. Table 2 summarises some of the coral associated microbiome abundance and diversity related to health status includes geographical distance, anthropogenic effect, and thermal regimes. So, coral microbiome, including bacteria and microalgae, contribute to coral resilience by undergoing special shifts under environmental stresses. These shifts could be towards increasing or decreasing in abundance or even by undergoing mutations which could be vertically transferred to the offspring. This leads to coral acclimatization and then adaptation to challenging environments (Fig. 3).

\section{Microbial Community in Relation to Coral Diseases and Coral Microbialization}

Microbes cause coral diseases either directly through biotic factors or indirectly after coral exposed to one of the abiotic stresses (Fig. 4). Among coral diseases caused by pathogenic microbes (biotic factors); Black Aggressive Band, Black Band Disease, Fungal Infection, Bacterial Infection, Black Overgrowing Cyanophyta, and Lethal Orange Disease (Table 3) (Fig. 5). Although abiotic coral diseases are usually 
Table 2. Influence of different health status and geographical distance on the structure of coral microbiome.

\begin{tabular}{|c|c|c|c|c|}
\hline \multicolumn{5}{|c|}{ Coral } \\
\hline Species & Health status & $\begin{array}{l}\text { Geographical } \\
\text { information }\end{array}$ & Abundance of Microbial community $\%$ & References \\
\hline \multirow[b]{2}{*}{ Acropora aspera } & Healthy & \multirow{8}{*}{ Indonesian seas } & $\begin{array}{c}\text { Fusibacter }>70 \% \\
\quad \text { Vibrio }>50 \%\end{array}$ & \multirow{8}{*}{ [115] } \\
\hline & Infected & & $\begin{array}{c}\text { Fusibacter }<25 \% \\
\text { Vibrio }<10 \% \\
\text { WH1-8 }<10 \%\end{array}$ & \\
\hline \multirow{2}{*}{ Acropora formosa } & Healthy & & $\begin{array}{l}\text { Fusibacter } 74.5>\% \\
\text { WH1-8 }>20 \%\end{array}$ & \\
\hline & Infected & & $\begin{array}{c}\text { Fusibacter }>82.5 \% \\
\text { WH1-8 }>10 \%\end{array}$ & \\
\hline \multirow{2}{*}{ Cyphastrea sp. } & Healthy & & $\begin{array}{c}\text { Fusibacter }>55.5 \% \\
\text { WH1- }>30 \%\end{array}$ & \\
\hline & Infected & & Fusibacter $>77 \%$ & \\
\hline \multirow[t]{2}{*}{ Isopora sp. } & Healthy & & $\begin{array}{c}\text { Fusibacter } 57 \% \\
\text { Acrobacter }>20 \% \\
\text { Clostridium } 10 \% \\
\text { WH1-8 } 3 \%\end{array}$ & \\
\hline & Infected & & $\begin{array}{c}\text { Acrobacter } 40 \% \\
\text { Fusibacter }>4 \\
\text { WH1-8 3\% }\end{array}$ & \\
\hline $\begin{array}{l}\text { Fungia echinata } \\
\text { mucus }\end{array}$ & Healthy & Andaman Sea & $\begin{array}{c}\text { Gammaproteobacteria }(64.7 \%) \text {, Alphaproteobacteria } \\
(3.5 \%) \text { Betaproteobacteria, Flavobacteriia, Clostridia, } \\
\text { Deltaproteobacteria, and Bacilli }<0.1-0.2 \%)\end{array}$ & {$[117]$} \\
\hline \multirow{2}{*}{$\begin{array}{l}\text { Scleronephthya } \\
\text { gracillimum }\end{array}$} & \multirow[t]{2}{*}{ Healthy } & $\begin{array}{l}\text { Japan } \\
\text { Korea }\end{array}$ & Endozoicimonaceae & \multirow{2}{*}{ [19] } \\
\hline & & Taiwan & Mycoplasma & \\
\hline \multirow{2}{*}{$\begin{array}{c}\text { Pseudodiploria } \\
\text { strigosa }\end{array}$} & \multirow{2}{*}{ Healthy } & $\begin{array}{l}\text { Inner reef from } \\
\text { Bermuda archipelago }\end{array}$ & $\begin{array}{c}\text { Gammaproteobacteria, Mollicutes, Bacilli, } \\
\text { Flavobacteria }\end{array}$ & [117] \\
\hline & & $\begin{array}{l}\text { Outer reef from } \\
\text { Bermuda archipelago }\end{array}$ & Methanobacteria & {$[117]$} \\
\hline
\end{tabular}

A sample for comparative analysis of coral associated microbial community abundance using health status and geographical distances is summarised. Analysis of healthy and infected different coral associated microbial community indicated the abundance of Fusibacter with almost all of the tested healthy Acropora aspera, Acropora Formosa, Cyphastrea sp. and Isopora sp. with different ranges. Interestingly, Vibrio sp., was highly abundant in only one infected species of Cyphastrea sp. while showed less abundance in infected Acropora aspera. Analysis also indicated abundance of Acrobacter with infected Isopora sp. On the other hand, geographical differences have also affected the abundance and diversity of bacterial species associated with corals such as Scleronephthya gracillimum. Although Taiwan showed less abundance of Endozoicimonaceae than detected in Japan and Korea, but it presented greater diversity. This may be due to different surrounding parameters among assigned sites, or due to coral reacting to environmental conditions.

caused by exposure to environmental stresses either by climate change or by anthropogenic input (Fig. 5c, d), these environmental disturbances in turn lead to weakening of host immunity and increase the growth rate of opportunistic microorganisms resulting in shift of the microbial population in coral tissue and mucus layer; known as 'Coral reef microbialization'. However, density and dynamics of associated bacteria make it hard to predict the cost of these changes [48] Zhang [43]. Coral disease is usually caused by a change in environmental and anthropogenic parameters which allow invasion by pathogenic species in addition to the change in the beneficial microbial composition [4]. This is the case in the Great Barrier Reef [60], as well as the
Indo-Pacific region [71], where elevation in temperature affects health and productivity of corals.

On the other hand, few publications have reported diseases of corals in the Red sea, such as black band disease, skeletal eroding band and white syndrome. Surveys in 2008 and 2010 on coral cover in the reef of Yongxing Island, South China Sea reported rapid mortality of corals due to black band disease caused by the invasion of T. hosinota. However, anthropogenic disturbances as well as heat stress response in the form of bleaching should also be accounted for this coral decline [72].

A recent study [59] exposed Porites compressa to four stressors to assess compositional and functional 
shift in associated coral microbial patterns. Effect of elevated temperature, increased nutrients level, dissolved organic carbon and decreased $\mathrm{pH}$ were tested. Metagenomic analysis revealed an increase in the abundance of nitrogen and sulfur cycling genes in addition to genes involved in resistance, pathogenicity, locomotion, lipid breakdown, and secondary metabolism. Moreover, few members of the microbial composition such as Vibrio sp. can intensely alter the health performance of the coral microbiome [59] leading to bleaching which can also be caused by elevated temperature (Fig. 5a, b). Coral density, intensity of coral bleaching and decline of water quality are believed to be the main modes of disease transmission [73]. Generally, the response of the coral microbiome to environmental stresses is reliable across variant disturbances,

a)

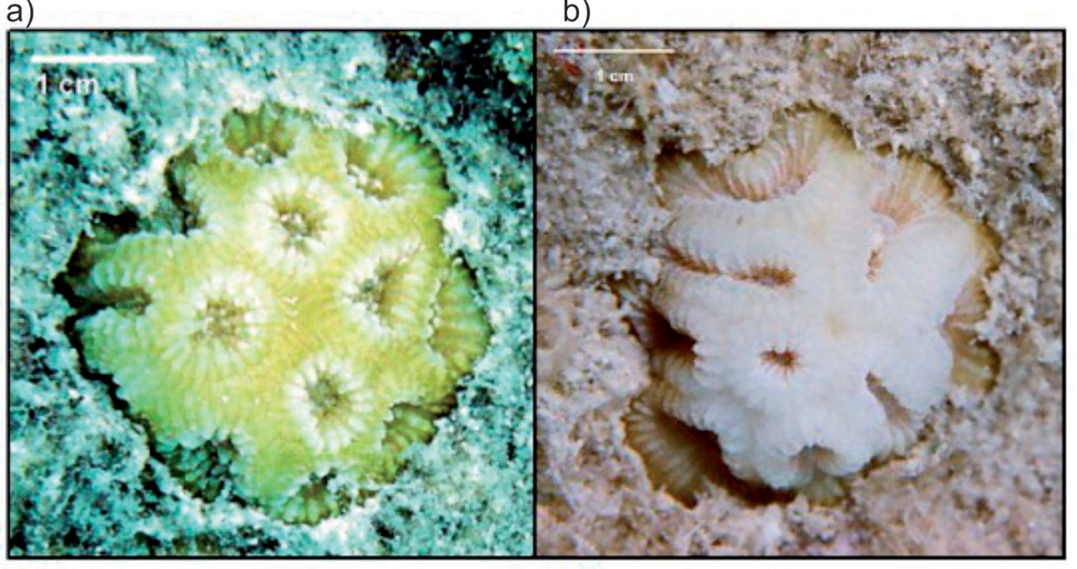

c)

d)

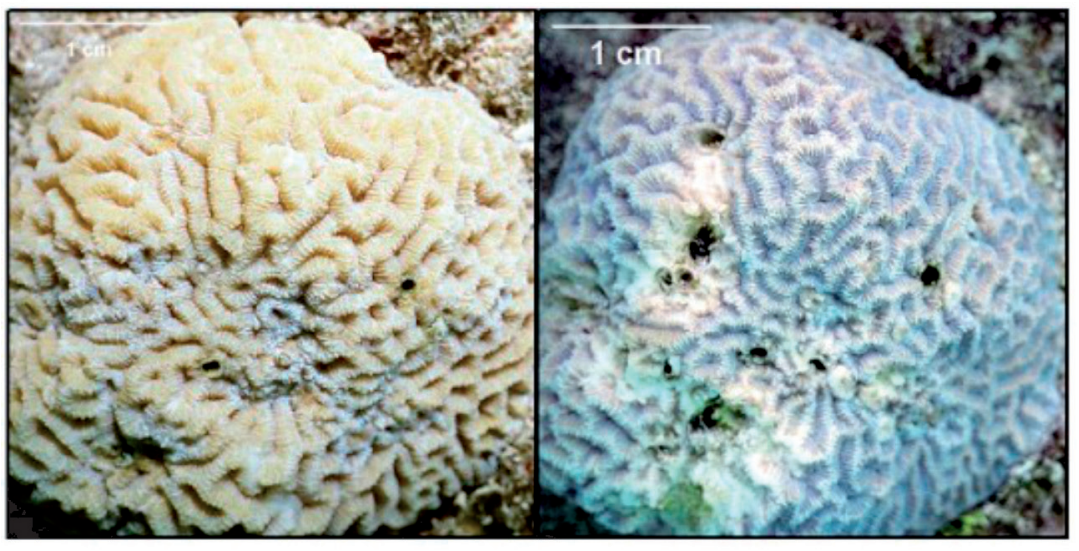

e)

f)

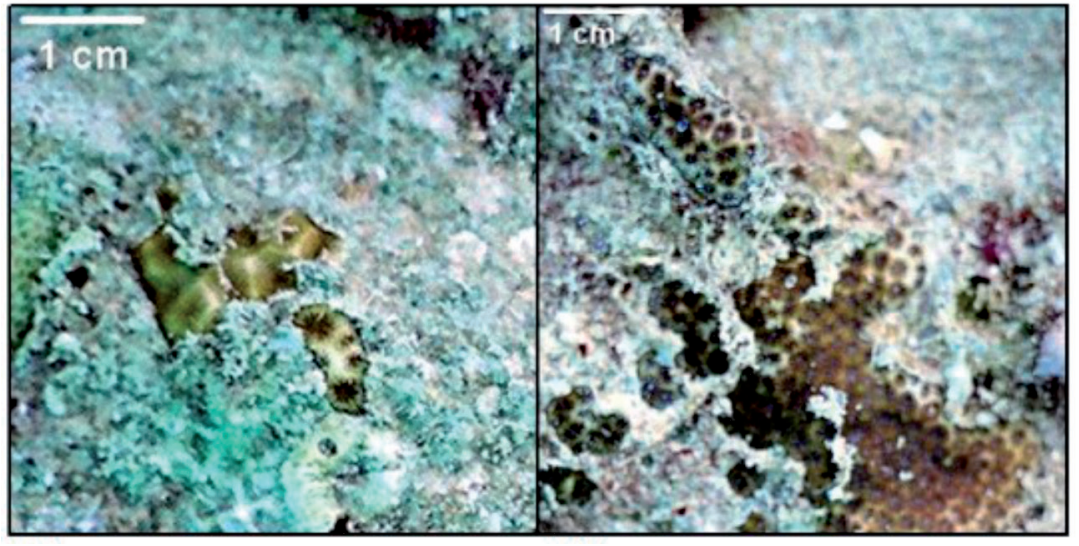

Fig. 4. Interruption of coral development in Hurgada, Red Sea, over three months period due to stresses: (a, b) Fish bioerosion of a $21.86 \mathrm{~cm}^{2}$ colony of Favia veroni (According to taxonomical identification by Moll and Borel-Best, 1984). (c, d) Bleaching of $10.3 \mathrm{~cm}^{2}$ colony of Goniastrea pectinata (According to taxonomical identification by Ehrenberg, 1834). (e, f) Biofouling of $7.2 \mathrm{~cm}^{2}$ colony of Leptastrea purpurea (According to taxonomical identification by Dana, 1846). All the above colonies have reached complete degradation after one year from first monitoring. (Photo credit: Amro Abd-Elgawad). 
Table 3. Common coral biotic and abiotic stressors.

\begin{tabular}{|c|c|c|c|c|}
\hline Disease & Symptoms & Abiotic stressor & Biotic stressor & References \\
\hline Black Band & $\begin{array}{l}\text { Formation of a black band on } \\
\text { the surface of the coral. The } \\
\text { pathogenic bacteria completely } \\
\text { degrade the coral tissue. }\end{array}$ & & $\begin{array}{l}\text { Phormidium corallyticum } \\
\text { is one of more than } 500 \\
\text { species found associated } \\
\text { with this disease. }\end{array}$ & [118] \\
\hline White Band & $\begin{array}{l}\text { Complete coral tissue } \\
\text { degradation } \\
\text { (Acroporid-specific) }\end{array}$ & & $\begin{array}{l}\text { A shift from domination } \\
\text { by Psuedomonads to } \\
\text { domination by Vibrio } \\
\text { carchariae. }\end{array}$ & [119] \\
\hline White Plaque & $\begin{array}{l}\text { Lesions which expand and } \\
\text { develops as a band to cover the } \\
\text { coral colony. }\end{array}$ & & $\begin{array}{l}\text { Aurantimonas coralicida } \\
\text { and other bacteria }\end{array}$ & [118] \\
\hline Bleaching & $\begin{array}{c}\text { Discolouration of coral colony } \\
\text { with degradation of coral } \\
\text { tissue. }\end{array}$ & $\begin{array}{l}\text { Elevated temperature, ocean } \\
\text { acidification, UV radiation and } \\
\text { pollution cause migration of } \\
\text { Zooxanthellae and whitening of } \\
\text { coral colonies }\end{array}$ & & [2] \\
\hline $\begin{array}{l}\text { Bacterial } \\
\text { Bleaching }\end{array}$ & $\begin{array}{c}\text { Discolouration of the coral } \\
\text { colony with the insider tissue } \\
\text { intact }\end{array}$ & & $\begin{array}{c}\text { Vibrio shiloi } \\
\text { and V.patogonica }\end{array}$ & {$[120]$} \\
\hline $\begin{array}{l}\text { Fungal Infection } \\
\text { (Aspergillosis) }\end{array}$ & Sea Fans & & Fungus Aspergillus sydowii, & [121] \\
\hline Dark Spot & $\begin{array}{l}\text { Small, circular areas of dark } \\
\text { brown or purple spots that } \\
\text { increase by time. }\end{array}$ & $\begin{array}{l}\text { Unknown, might be accumulation } \\
\text { of zooxanthellae pigments, an } \\
\text { endolithic fungus, or accumulations } \\
\text { of zymogen granules as a defensive } \\
\text { against endolithic invasion. }\end{array}$ & & [118] \\
\hline Yellow Band & $\begin{array}{l}\text { Yellow blotches that continue } \\
\text { to an o-ring shapes. }\end{array}$ & Unknown & & [118] \\
\hline $\begin{array}{l}\text { Caribbean Ciliate } \\
\text { Infection }\end{array}$ & $\begin{array}{l}\text { Tissue loss disease resembling } \\
\text { black band disease. }\end{array}$ & & $\begin{array}{c}\text { Ciliate protozoan } \\
\text { Genus Halofoliculina }\end{array}$ & [118] \\
\hline $\begin{array}{l}\text { Black } \\
\text { Overgrowing } \\
\text { Cyanophyta }\end{array}$ & $\begin{array}{l}\text { Species of Cyanophyta } \\
\text { overgrow the coral, and feed } \\
\text { on the polyps or erode the } \\
\text { coral skeleton, cause collapse } \\
\text { of a branching coral. }\end{array}$ & & $\begin{array}{l}\text { Calothrix crustacea } \\
\text { C. scopulorum }\end{array}$ & [118] \\
\hline
\end{tabular}

characterized by an increase in the relative abundances of Vibrionales, Flavobacteriales, Rhodobacterales, and Alteromonadales [45].

\section{Role of Microbiome in Coral Resilience}

The ability of corals to tolerate heat stress is a key factor that reflects their capacity to adapt to climate change. Coral holobiont includes host coral, the dianoflagellate microalgae, bacteria, virus, fungi and archaea [74]. Coral species exhibit their tolerance through carrying leading genes which support their resistance $[75,76]$ or through shift in their microbial composition [18] such as species and genotype of Symbiodiniacea and bacteria associated with corals [14].

In addition to their role in cycling carbon, nitrogen and sulphur, osmoregulation and oxidative stress responses in corals and on coral reef [77], microbes associated with corals have a fundamental participation in regulation of larval attachment, and pathogen abundance under disturbed environments, hence, controlling the overall adaptation of coral reef ecosystems to climate change [78]. Not only the bacteria associated with corals but also the surrounding bacteria may play a role in the early stages of coral growth. For example, $\gamma$-protobacteria which has been reported to grow as a film on the surface of Crustose Coraline Algae (CCA) proved to perform a fundamental role in larval settlement as well as metamorphosis [79].

A high number of antibacterial genes have been reported in genomes from different corals [78]. These are known to help to secure corals against infecting pathogens. The fundamental role of specific bacteria is indicated by their vertical transmission and conservation in different coral tissues [13, 80]. Unlike the high variability of microbiome present in outer mucus cover, the microbial population associated 
a)

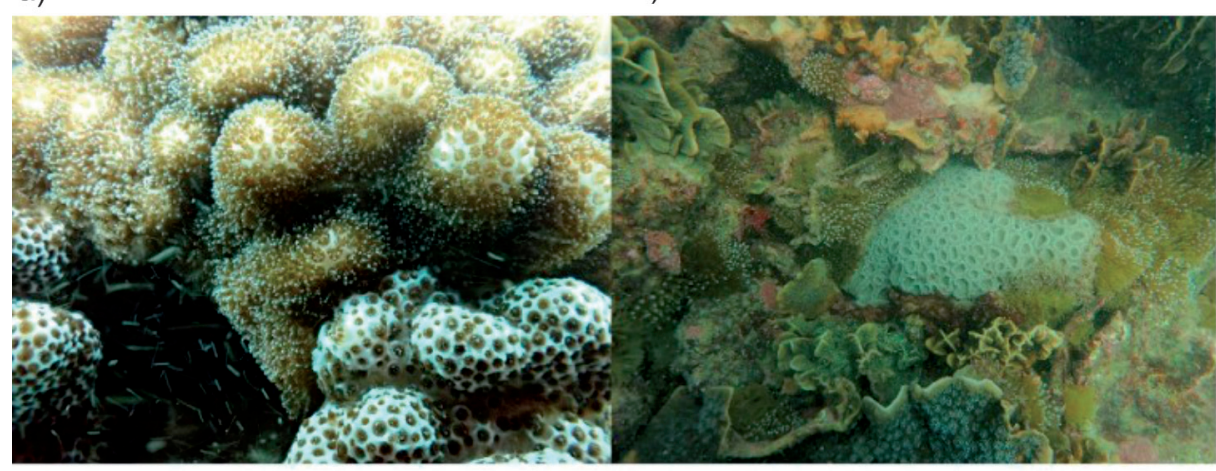

c)

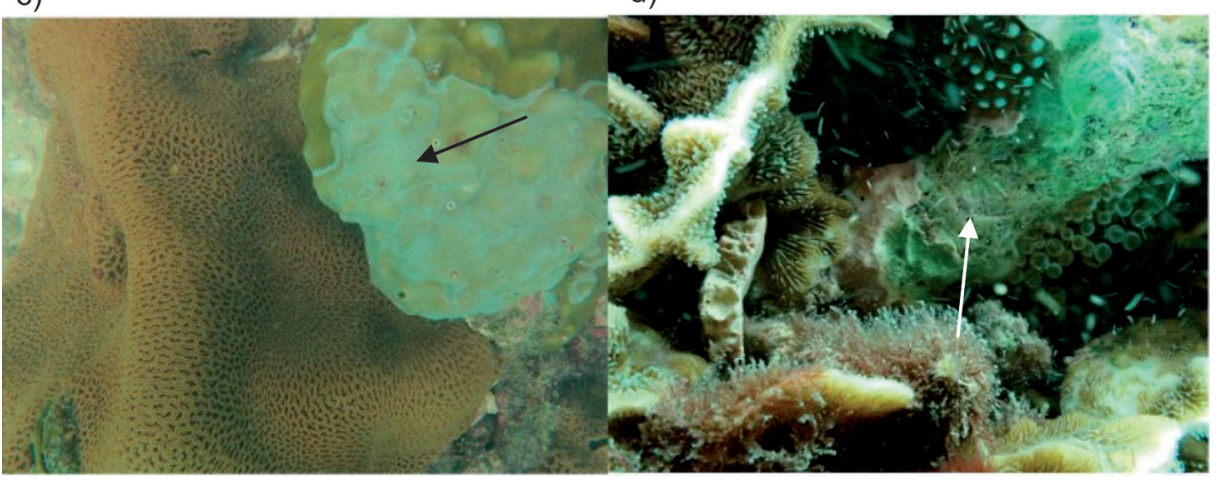

Fig. 5. Impacted coral colonies from Weizhou Island, China. a) and b) Bleaching events which could happen due to bacterial infection or temperature elevation. Arrows in c) and d) indicate the different appearance of coral diseases and coral bleaching due to microbial shift and migration of microalgae following environmental stress. (Photo credit: Amro Abd-Elgawad).

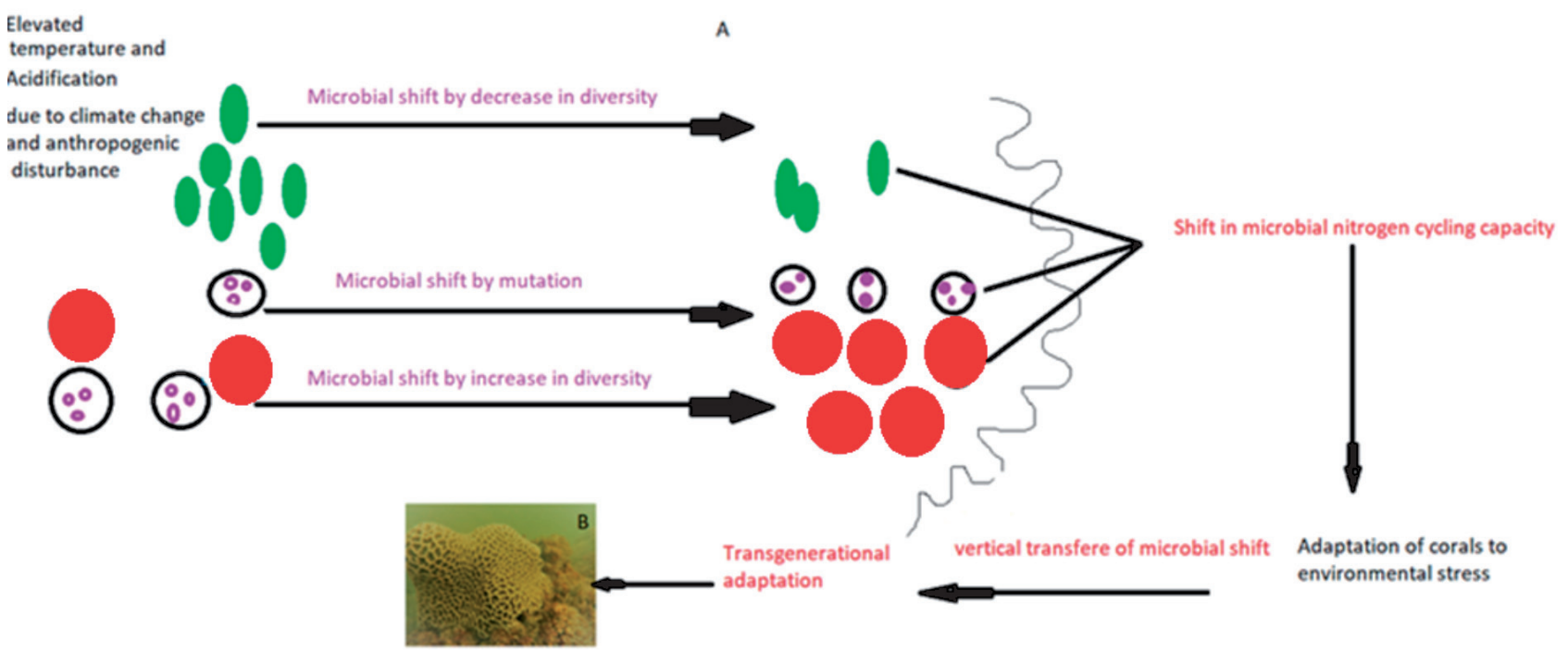

Fig. 6. A) Role of microbiome in coral resilience. Coral microbiome participates in coral resilience through many mechanisms; they may adapt to elevated temperature through decrease and increase in diversity, or through mutations which results in more thermotolerant genes. The new microbial community pattern will in turn lead to adaptation of corals to disturbing environmental conditions. Vertical transfer of the new microbial pattern to the next coral generation expands the area of adapted corals.

B) Healthy coral colony found in a severely damaged site by climate change and anthropogenic disturbances in Weizhou Island, China. The coral colony shows large size and healthy colour indicating good adaptation to the surrounding impact most likely due to the provided resilience by the associated microbiome. (Photo credit: Amro Abd-Elgawad). 
with the insider coral tissues is not as much variable which tends to be consistent with specificity to their host [80]. A bacterial shift which is presented by a decrease or increase in the number of specific groups in addition to undergoing mutations causes changes in metabolic productivity in a direction favoring the new disturbed conditions (Fig. 6). For instance, movement of corals to water with higher temperature resulted in a change of symbiotic bacterial population related to thermotolerance [21]. Also, high bacterial diversity in deep water suggests they may have an additional role concerning relation to nutrient cycling $[81,82]$. So, as holobionts, the short life cycle and fast growth rate of microbes together with their diverse genetic material, provide corals with different mechanisms of adaptation to environmental disturbances including climate change and human impacts.

\section{Coral Restoration}

\section{Limitation of Traditional Methods}

Climate change distresses coral reefs in several ways. Sea surface temperatures (SST) beyond the thermal stability of corals can cause break down of the partnership between corals and their holobionts (including microalgae and bacterial communities), leading to coral bleaching events [60]. Also, a high level of $\mathrm{CO}_{2}$ increases the acidity of the surrounding seawater causing difficulties in coral calcification processes for building skeletons [3]. Consequently, the ocean acidification will adversely affect bacterial pattern associated with the corals [4]. Apart from climate change, other anthropogenic activities severely contribute to coral decline, such as nutrient augmentation, poor water pollution and eutrophication [83].

Many different techniques have been invented as dispirit needs are growing to rescue coral reefs from decline. Coral restoration and rehabilitation involved many different methods, for example, transplantation, coral gardening, micro-fragmentation, genetic diversity in asexual propagation, larval enhancement, artificial reefs, substratum stabilisation, substratum enhancement with electricity. The restoration methodologies currently used have limited scientific publications with good replicable data to judge persistence, mortality, recovery, and development of colonies during various stages of the restoration mission. So far, they have not reached a so-called sustained coral recovery; possibly, because coral restoration needs close and frequent management, observation, and maintenance for a very long period. This is not applicable with short term projects applied for coral restoration especially with often repeated disturbances that do not allow establishment of new coral recruits.

Projects involved in coral restoration should aim to re-establish the breeding population of the reef ecosystem [84, 85]. Such populations should not need continuing interferences and should improve autonomous larval attachment, metamorphosis and settlement. The fundamental target of self-sustaining coral breed is a missing key in most of coral reef restoration missions. This is due to the average monitoring period of one year which is far beyond the time needed by corals to reach a satisfying stage of recovery [86].

Most of the latest coral restoration techniques do not maintain genetic diversity of corals. Almost all studies are interested in using specific species of corals which proved to give good results in asexual propagation such as Acroporids [87]. The clonal methods commonly used in coral gardening lack the variation in genotypes and hence decrease coral adaptation [86]. Supported fertilization [88] or creating nurseries from coral larvae [89] could be the solution to obtain genetic variation in coral gardening [86] but still needs more investigation for successful application.

High cost, poor efficiency and small-scale application are also limitations to strengthen the coral resilience to environmental disturbances. It has become a warning that while coral restoration plans aim to fight coral reef decline, on the contrary, some techniques may participate in the loss of some reef habitat. For example, some artificial reef models made of concrete and cement can directly contribute to climate change, because these materials used emit not less than 5-7\% of the global carbon [86]. Furthermore, $(\sim 60 \%)$ of the ongoing coral restoration projects use plastic materials to attach coral fragments to the models of restoration, as well as steel which is also commonly used in coral restoration [90]. All these materials can accumulate on reefs, influencing the microbial community as well as all forms of life included in the coral reef ecosystem.

\section{Microbial Management of Coral Reef \\ Coral Microbiome as Bioindicators of Coral Threat}

Usually, coral decline is measured by the health status of the coral reef including apparent diseases or bleaching and the benthic composition in relation to the environmental stress [91]. However, this diagnosis is not very beneficial as it occurs after corals reach advanced deterioration. More rapid response to the environmental change could be a solution to predict coral threat [25]. The use of coral microbial composition as a possible indicator to climate change has been suggested by many publications $[25,92]$. As the case of using a microbialization score in water, for measuring human impact, also measuring microbial shift (increase or decrease in some groups) especially in the surrounding water can assist in the prediction of the coral decline as they are more sensitive to environmental change in contrast to coral associated microbiome which is more species- specific [25]. However, not enough data 
is available on a long-term monitoring for microbial composition during different environmental stresses. $[25,93]$.

\section{The Possible Role of the Microbiome in Coral Reef Restoration}

Understanding the role of microorganisms in preserving coral health and ecological functioning, together with an appreciation of possible integration in restoration and management of declining coral species is growing [94]. In the same manner as introducing microbiome engineering (ME) for soil and plant microbiota for obtaining desirable traits; coral ME has been also explored but still at its early stages [95]. In order to perform ME in corals, two tasks need to be fully explored: 1) Identification of beneficial functional genes of the microbiota; and this can only be done through functional genomic studies such as metatranscriptomics and metabolomics. 2) Identification of host-microbe interaction specificity, otherwise the inoculated microbiota will only provide a short-term host resilience. Fragmentation and transplantation of resistant coral colonies have been lately used without looking at the inside of the resistant corals and the driver of their tolerance to environmental stress as an indirect way to enhance coral resilience, however, the most important limitation of this methodology is the no reproducibility plus the long time needed for the coral generations to appear (Evolution 21; www.aims.gov.au/evolution-21). Another more precise methodology involved direct inoculation of coral species with beneficial microbiota such as heat resistant symbiodineace members or bacteria which are previously known for giving capability for water soluble oil degradation or supports heat resistance [96]. Current studies detected shuffling of symbiotic clades following coral bleaching events due to heat stress leading to new microbial community composition. This may occur through horizontal transfer of tolerant genes or symbiont switching. The domination of heat tolerant symbionts following sever bleaching supports the Adaptive Bleaching Hypothesis (ABH) [97]. Recently, attempts have been made to introduce modified recruits of heat-resistant corals through hybridization between tolerant and bleached corals [98]. Hybridization involves gene transfer of natural healthy resistant beneficial microorganisms for corals or even the genetically engineered ones the diseased or unhealthy corals as an attempt for resistance transformation [99, 100] and hence increases genetic diversity, which could increase the adaptability of new corals to the environmental conditions. The alternative approach is known as assisted evolution which involves production of coral species with enhanced tolerance by increasing coral microbiome evolutionary changes [15]. However, it is still early to know if this technique could be used for the long term and what will be the implications on the whole ecosystem. Another possibility is the direct implementation of beneficial microbial cues to corals in coral restoration. This could be done through enhancing coral larval attachments and metamorphosis as well as preventing colonization of harmful competitive microbes [101]. In addition, Phage therapy has also been suggested for controlling spread of coral bacterial diseases [102]. However, all the above methods have not been yet well established and needs more attention for further development and to test their feasibility in coral restoration.

Microbial symbionts with short life cycles will have more chance to rapidly adapt to the environment than their coral hosts that is too slow to keep up with the speed of climate change [103]. Establishment of new tolerant coral mutants requires several generations, signifying that only short life cycle model organisms could succeed to adapt at a considerable rate in relation to the fast-environmental disturbance [104].

As the trend of coral restoration grows rapidly globally, we encourage researchers to use environmentally friendly substitutes and self-breeding biosource materials such as high tolerant microbiome and genetically modified bacterial species which favour coral larval attachment and metamorphosis. Rapid growth and cell division of bacterial microbiome makes them unique with short life cycles for better experimenting the adaptation to environmental stresses. Microbial restoration is also believed to be ideal as a large scale costless and environmental free self-sustaining coral restoration tool. It is the time to incorporate microorganisms in the ecological studies on coral reef and in the restoration policy to build a database of coral reef function and production including these microorganisms [94].

\section{Conclusion}

Coral reef is one of the most reproductive marine ecosystems, as well as a carbon capturing and sequestering ecosystem. Using of Corals in blue carbon mechanism is a promising and hopeful trend to help in reducing water acidification [8]. Yet, facing tremendous deterioration due to global environmental stresses [105]. They harbour diverse and abundant microbiome associated with nutrient cycling, modifications in coral health, symptoms of specific diseases and/or bleaching and resilience to climate change or anthropogenic impact [106, 107]. As microbial community of coral reef has been described as predictors of environmental disturbances in coral reef ecosystems, this suggests that coral acclimatizes to environmental disturbances by a shift in their microbial pattern [18, 108] which allows them to be used as indicators for environmental disturbance to reinforce effective application of coral repair policies [25]. Recently, significant attraction is growing towards coral microbiome as a possible approach in sustaining coral fitness and gaining coral resilience $[96,97]$. Separate studies using metabarcoding [110], metagenomics, metatranscriptomics and 
metabolomics [111] have surely added to the baseline of coral microbiome. Hence, comes the urgent need for broad management and extensive comparison of available data on coral microbial population worldwide. Developing this kind of baseline information allows to link the structure of coral microbiome with biotic and abiotic stressors and shed light on the origin of coral diseases. Gathering of these data will assist the rescuing of coral reefs and provide novel sights for the emerging microbiome engineering trend and it add-value in coral reef restoration [15].

However, combined studies of the three techniques are needed to correlate diversity and abundance to the metabolic functions of coral microbiome. Furthermore, to predict their response to environmental changes and hence, save more time for coral rescuing before reaching final stages of deterioration.

By knowing the succession of events during coral decline, it is possible to design a tool for coral restoration which can serve coral microbial community instead of working on the coral itself. After presenting the high value of microbial community in maintaining coral reef health, we hence call scientists engaged in coral restoration, to avoid using harmful structures or materials to microbes in their models of restoration.

\section{Acknowledgments}

This work was funded by The Scientific Research Foundation of the Third Institute of Oceanography, MNR [2020001], China APEC Foundation [HV01190101(1)], Xiamen, Marine and Fishery Development Special Foundation [19CZP011HJ08], and The Special Scientific Research Fund of Public Welfare Profession of China [201405038].

\section{Conflict of Interest}

The authors declare no conflict of interest.

\section{References}

1. FRANÇA F.M., BENKWITT C.E., PERALTA G., ROBINSON J.P.W., GRAHAM N.A.J., TYLIANAKIS J.M., et al. Climatic and local stressor interactions threaten tropical forests and coral reefs. Philosophical Transactions of the Royal Society B: Biological Sciences; 375 (1794), 20190116, 2020.

2. HOEGH-GULDBERG O., POLOCZANSKA E.S., SKIRVING W., DOVE S. Coral Reef Ecosystems under Climate Change and Ocean Acidification. Frontiers in Marine Science; 4 (158), 2017.

3. KLEYPAS J., LANGDON C. Coral Reefs and Changing Seawater Carbonate Chemistry. 2013.

4. MERON D., ATIAS E., IASUR KRUH L., ELIFANTZ H., MINZ D., FINE M., et al. The impact of reduced $\mathrm{pH}$ on the microbial community of the coral Acropora eurystoma. The ISME Journal; 5 (1), 51, 2011.
5. FEELY R.A., WANNINKHOF R., LANDSCHÜTZER P., CARTER B.R., TRIÑANES J.A. Global ocean carbon cycle [in "State of the Climate in 2016"]. Bulletin of the American Meteorological Society; 98, S89, 2017.

6. ALBRIGHT R., BENTHUYSEN J., CANTIN N., CALDEIRA K., ANTHONY K. Coral reef metabolism and carbon chemistry dynamics of a coral reef flat. Geophysical Research Letters; 42 (10), 3980, 2015.

7. GAO Y., YU G., YANG T., JIA Y., HE N., ZHUANG J. New insight into global blue carbon estimation under human activity in land-sea interaction area: A case study of China. Earth-Science Reviews; 159, 36, 2016.

8. CHEN Y., XU C. Exploring New Blue Carbon Plants for Sustainable Ecosystems. Trends in Plant Science; 25 (11), 1067, 2020.

9. RICHARD S. Microalgae: The Potential for Carbon Capture. BioScience; 60 (9), 722, 2010.

10. STEPHENS E., ROSS I.L., KING Z., MUSSGNUG J.H., KRUSE O., POSTEN C., et al. An economic and technical evaluation of microalgal biofuels. Nature Biotechnology; 28 (2), 126, 2010.

11. WEYER K.M., BUSH D.R., DARZINS A., WILLSON B.D. Theoretical Maximum Algal Oil Production. BioEnergy Research; 3 (2), 204, 20103.

12. KNOWLTON N., ROHWER F. Multispecies Microbial Mutualisms on Coral Reefs: The Host as a Habitat. The American Naturalist; 162 (S4), S51, 2003.

13. NEAVE M.J., RACHMAWATI R., XUN L., MICHELL C.T., BOURNE D.G., APPRILL A., et al. Differential specificity between closely related corals and abundant Endozoicomonas endosymbionts across global scales. The ISME Journal; 11 (1), 186, 2017.

14. LAJEUNESSE T.C., PARKINSON J.E., GABRIELSON P.W., JEONG H.J., REIMER J.D., VOOLSTRA C.R., et al. Systematic Revision of Symbiodiniaceae Highlights the Antiquity and Diversity of Coral Endosymbionts. Current Biology; 28 (16), 2570-80.e6, 2018.

15. [VAN OPPEN M.J.H., BLACKALL L.L. Coral microbiome dynamics, functions and design in a changing world. Nature Reviews Microbiology; 17 (9), 557, 2019.

16. BERNASCONI R., STAT M., KOENDERS A., PAPARINI A., BUNCE M., HUGGETT M.J. Establishment of Coral-Bacteria Symbioses Reveal Changes in the Core Bacterial Community With Host Ontogeny. Frontiers in Microbiology; 10 (1529), 2019.

17. BANG C., DAGAN T., DEINES P., DUBILIER N., DUSCHL W.J., FRAUNE S., et al. Metaorganisms in extreme environments: do microbes play a role in organismal adaptation? Zoology; 127, 1, 2018.

18. ZIEGLER M., GRUPSTRA C.G.B., BARRETO M.M., EATON M., BAOMAR J., ZUBIER K., et al. Coral bacterial community structure responds to environmental change in a host-specific manner. Nature Communications; 10 (1), 3092, 2019.

19. WOO S., YANG S.H., CHEN H.J., TSENG Y.F., HWANG S.J., DE PALMAS S., et al. Geographical variations in bacterial communities associated with soft coral Scleronephthya gracillimum. PLoS One; 12 (8), e0183663, 2017.

20. NEAVE M.J., APPRILL A., AEBY G., MIYAKE S., VOOLSTRA C.R. The microbial community of Red Sea coral reefs. In: C Voolstra and M Berumen (eds), editor Coral Reefs of the Red Sea. Coral Reefs of the World. Springer; 2019.

21. ZIEGLER M., SENECA F.O., YUM L.K., PALUMBI S.R., VOOLSTRA C.R. Bacterial community dynamics 
are linked to patterns of coral heat tolerance. Nature Communications; 8, 14213, 2017.

22. MEIRELLES P.M., SOARES A.C., OLIVEIRA L., LEOMIL L., APPOLINARIO L.R., FRANCINI-FILHO R.B., et al. Metagenomics of Coral Reefs Under Phase Shift and High Hydrodynamics. Frontiers in Microbiology; 9 (2203), 2018.

23. SILVEIRA C.B., CAVALCANTI G.S., WALTER J.M., SILVA-LIMA A.W., DINSDALE E.A., BOURNE D.G., et al. Microbial processes driving coral reef organic carbon flow. FEMS Microbiol Rev; 41 (4), 575, 2017.

24. LEE S.T.M., DAVY S.K., TANG S.-L., KENCH P.S. Mucus Sugar Content Shapes the Bacterial Community Structure in Thermally Stressed Acropora muricata. Frontiers in Microbiology; 7 (371), 2016.

25. GLASL B., BOURNE D.G., FRADE P.R., THOMAS T., SCHAFFELKE B., WEBSTER N.S. Microbial indicators of environmental perturbations in coral reef ecosystems. Microbiome; 7 (1), 94, 2019.

26. DUCKLOW H.W. The biomass, production and fate of bacteria in coral reefs. Dubinsky Z (ed) Ecosystems of the world 25. Elsevier, Amsterdam; 265, 1990.

27. NEALSON K.H. SEDIMENT BACTERIA: Who's There, What Are They Doing, and What's New? Annual Review of Earth and Planetary Sciences; 25 (1), 403-34, 1997.

28. HEWSON I., FUHRMAN J. Spatial and vertical biogeography of coral reef sediment bacterial and diazotroph communities. Marine Ecology-progress Series - MAR ECOL-PROGR SER; 306, 79, 2006.

29. SCHÖTTNER S., PFITZNER B., GRÜNKE S., RASHEED M., WILD C., RAMETTE A. Drivers of bacterial diversity dynamics in permeable carbonate and silicate coral reef sands from the Red Sea. Environmental Microbiology; 13 (7), 1815, 2011.

30. BEDNARZ V., VAN HOYTEMA N., CARDINI U., NAUMANN M., AL-RSHAIDAT M., WILD C. Dinitrogen fixation and primary productivity by carbonate and silicate reef sand communities of the Northern Red Sea. Marine Ecology Progress Series; 527, 47, 2015.

31. UTHICKE S., MCGUIRE K. Bacterial communities in Great Barrier Reef calcareous sediments: Contrasting 16S rDNA libraries from nearshore and outer shelf reefs. Estuarine, Coastal and Shelf Science; 72 (1), 188, 2007.

32. TOUT J., JEFFRIES T.C., WEBSTER N.S., STOCKER R., RALPH P.J., SEYMOUR J.R. Variability in Microbial Community Composition and Function Between Different Niches Within a Coral Reef. Microbial Ecology; 67 (3), $540,2014$.

33. FURBY K.A., APPRILL A., CERVINO J.M., OSSOLINSKI J.E., HUGHEN K.A. Incidence of lesions on Fungiidae corals in the eastern Red Sea is related to water temperature and coastal pollution. Marine Environmental Research; 98, 29, 2014.

34. VOOLSTRA C., BERUMEN M. Coral Reefs of the Red Sea Coral Reefs of the World. Nature Switzerland AG.: Springer 2019.

35. BOELEN P., POST A.F., VELDHUIS M.J.W., BUMA A.J. Diel Patterns of UVBR-Induced DNA Damage in Picoplankton Size Fractions from the Gulf of Aqaba, Red Sea. Microbial Ecology; 44 (2), 164, 2002.

36. MUSCATINE L., PORTER J.W. Reef Corals: Mutualistic Symbioses Adapted to Nutrient-Poor Environments. BioScience; 27 (7), 454, 1977.

37. MUSCATINE L., PORTER J.W., KAPLAN I.R. Resource partitioning by reef corals as determined from stable isotope composition. Marine Biology; 100 (2), 185, 1989.
38. GOLDBERG W. Coral Food, Feeding, Nutrition, and Secretion: A Review. 377, 2018.

39. FALKOWSKI P.G., DUBINSKY Z., MUSCATINE L., PORTER J.W. Light and the Bioenergetics of a Symbiotic Coral. BioScience; 34 (11), 705, 1984.

40. SIVAGURU M., TODOROV L.G., FOUKE C.E., MUNRO C.M.O., FOUKE K.W., FOUKE K.E., et al. Corals regulate the distribution and abundance of Symbiodiniaceae and biomolecules in response to changing water depth and sea surface temperature. Scientific Reports; 11 (1), 2230, 2021.

41. POGOREUTZ C., RÄDECKER N., CÁRDENAS A., GÄRDES A., VOOLSTRA C.R., WILD C. Sugar enrichment provides evidence for a role of nitrogen fixation in coral bleaching. Global Change Biology; 23 (9), 3838, 2017.

42. POGOREUTZ C., RÄDECKER N., CÁRDENAS A., GÄRDES A., WILD C., VOOLSTRA C.R. Dominance of Endozoicomonas bacteria throughout coral bleaching and mortality suggests structural inflexibility of the Pocillopora verrucosa microbiome. Ecol Evol; 8 (4), 2240, 2018.

43. ZHANG Y.Y., LING J., YANG Q.S., WANG Y.S., SUN C.C., SUN H.Y., et al. The diversity of coral associated bacteria and the environmental factors affect their community variation. Ecotoxicology; 24 (7-8), 1467, 2015.

44. ZIEGLER M., ROIK A., PORTER A., ZUBIER K., MUDARRIS M.S., ORMOND R., et al. Coral microbial community dynamics in response to anthropogenic impacts near a major city in the central Red Sea. Marine Pollution Bulletin; 105 (2), 629, 2016.

45. MCDEVITT-IRWIN J.M., BAUM J.K., GARREN M., VEGA THURBER R.L. Responses of Coral-Associated Bacterial Communities to Local and Global Stressors. Frontiers in Marine Science; 4 (262), 2017.

46. CAI L., TIAN R.-M., ZHOU G., TONG H., WONG Y.H., ZHANG W., et al. Exploring coral microbiome assemblages in the South China Sea. Scientific Reports; 8 (1), 2428, 2018.

47. MOUCHKA M.E., HEWSON I., HARVELL C.D. CoralAssociated Bacterial Assemblages: Current Knowledge and the Potential for Climate-Driven Impacts. Integrative and Comparative Biology; 50 (4), 662, 2010.

48. RODER C., ARIF C., DANIELS C., WEIL E., VOOLSTRA C.R. Bacterial profiling of White Plague Disease across corals and oceans indicates a conserved and distinct disease microbiome. Molecular Ecology; 23 (4), 965, 2014.

49. RODER C., ARIF C., BAYER T., ARANDA M., DANIELS C., SHIBL A., et al. Bacterial profiling of White Plague Disease in a comparative coral species framework. The ISME Journal; 8 (1), 31, 2014.

50. BAYER T., NEAVE M.J., ALSHEIKH-HUSSAIN A., ARANDA M., YUM L.K., MINCER T., et al. The microbiome of the Red Sea coral Stylophora pistillata is dominated by tissue-associated Endozoicomonas bacteria. Applied and environmental microbiology; 79 (15), 4759, 2013.

51. OSMAN E.O., SUGGETT D.J., VOOLSTRA C.R., PETTAY D.T., CLARK D.R., POGOREUTZ C., et al. Coral microbiome composition along the northern Red Sea suggests high plasticity of bacterial and specificity of endosymbiotic dinoflagellate communities. Microbiome; 8 (1), 8, 2020.

52. POLLOCK F.J., MCMINDS R., SMITH S., BOURNE D.G., WILLIS B.L., MEDINA M., et al. Coral-associated 
bacteria demonstrate phylosymbiosis and cophylogeny. Nat Commun; 9 (1), 4921, 2018.

53. KOOPERMAN N., BEN-DOV E., KRAMARSKYWINTER E., BARAK Z., KUSHMARO A. Coral mucusassociated bacterial communities from natural and aquarium environments. FEMS Microbiology Letters; 276 (1), 106, 2007.

54. CARLOS C., TORRES T.T., OTTOBONI L.M.M. Bacterial communities and species-specific associations with the mucus of Brazilian coral species. Scientific Reports; 3, 1624, 2013.

55. ROBINSON J.P.W., WILSON S.K., GRAHAM N.A.J. Abiotic and biotic controls on coral recovery 16 years after mass bleaching. Coral Reefs; 38 (6), 1255, 2019.

56. GOLBERG K, PAVLOV V, MARKS RS, KUSHMARO A. Coral-associated bacteria, quorum sensing disrupters, and the regulation of biofouling. Biofouling; 29 (6), 669, 2013.

57. RICE M.M., EZZAT L., BURKEPILE D.E. Corallivory in the Anthropocene: Interactive Effects of Anthropogenic Stressors and Corallivory on Coral Reefs. Frontiers in Marine Science; 5 (525), 2019.

58. DAVIDSON T.M., ALTIERI A.H., RUIZ G.M., TORCHIN M.E. Bioerosion in a changing world: a conceptual framework. Ecology Letters; 21 (3), 422, 2018.

59. VEGA THURBER R., MYDLARZ L.D., BRANDT M., HARVELL D., WEIL E., RAYMUNDO L., et al. Deciphering Coral Disease Dynamics: Integrating Host, Microbiome, and the Changing Environment. Frontiers in Ecology and Evolution; 8 (402), 2020.

60. BOURNE D.G., WEBSTER N.S. Coral Reef Bacterial Communities. The Prokaryotes. Berlin, Heidelberg: Springer; 2013.

61. GONG S., JIN X., REN L., TAN Y., XIA X. Unraveling Heterogeneity of Coral Microbiome Assemblages in Tropical and Subtropical Corals in the South China Sea. Microorganisms; 8 (4), 2020.

62. LI S., YU K., SHI Q., CHEN T., ZHAO M., ZHAO $\mathrm{J}$. Interspecies and spatial diversity in the symbiotic zooxanthellae density in corals from northern South China Sea and its relationship to coral reef bleaching. Chinese Science Bulletin; 53 (2), 295, 2008.

63. CLARK T.R., CHEN X., LEONARD N.D., LIU F., GUO Y., ZENG T., et al. Episodic coral growth in China's subtropical coral communities linked to broad-scale climatic change. Geology; 47 (1), 79, 2018.

64. TANAKA Y., SUZUKI A., SAKAI K. Effects of elevated seawater temperature and phosphate enrichment on the crustose coralline alga Porolithon onkodes (Rhodophyta). Phycological Research; 65 (1), 51, 2017.

65. BOURNE D.G., MORROW K.M., WEBSTER N.S. Insights into the Coral Microbiome: Underpinning the Health and Resilience of Reef Ecosystems. Annual Review of Microbiology; 70 (1), 317, 2016.

66. JESSEN C., VILLA LIZCANO J.F., BAYER T., RODER C., ARANDA M., WILD C., et al. In-situ Effects of Eutrophication and Overfishing on Physiology and Bacterial Diversity of the Red Sea Coral Acropora hemprichii. PLOS ONE; 8 (4), e62091, 2013.

67. PINZÓN J.H., KAMEL B., BURGE C.A., HARVELL C.D., MEDINA M., WEIL E., et al. Whole transcriptome analysis reveals changes in expression of immune-related genes during and after bleaching in a reef-building coral. Royal Society Open Science; 2 (4), 140214, 2015.

68. FRADE P.R., GLASL B., MATTHEWS S.A., MELLIN C., SERRÃO E.A., WOLFE K., et al. Spatial patterns of microbial communities across surface waters of the Great Barrier Reef. Communications Biology; 3 (1), 442, 2020.

69. HUSSIEN E., JUHMANI A.-S., ALMASRI R., ALHORANI F., AL-SAGHIR M. Metagenomic analysis of microbial community associated with coral mucus from the Gulf of Aqaba. Heliyon; 5 (11), e02876, 2019.

70. DINSDALE E.A., EDWARDS R.A., HALL D., ANGLY F., BREITBART M., BRULC J.M., et al. Functional metagenomic profiling of nine biomes. Nature; 452 (7187), 629, 2008.

71. VARGAS-ÁNGEL B. Crustose coralline algal diseases in the U.S.-Affiliated Pacific Islands. Coral Reefs; 29 (4), 943, 20106.

72. SHI Q., LIU G.H., YAN H.Q., ZHANG H.L. Black Disease (Terpios hoshinota), A Probable Cause for the Rapid Coral Mortality at the Northern Reef of Yongxing Island in the South China Sea. AMBIO; 41 (5), 446, 2012.

73. HETZINGER S., PFEIFFER M., DULLO W.C., ZINKE J., GARBE-SCHÖNBERG D. A change in coral extension rates and stable isotopes after El Niño-induced coral bleaching and regional stress events. Scientific Reports; 6 (1), 32879, 2016.

74. ZHANG Y., YANG Q., LING J., LONG L., HUANG H., YIN J., et al. Shifting the microbiome of a coral holobiont and improving host physiology by inoculation with a potentially beneficial bacterial consortium. BMC Microbiology; 21 (1), 130, 2021.

75. DIXON GB, DAVIES SW, AGLYAMOVA GV, MEYER E, BAY LK, MATZ MV. Genomic determinants of coral heat tolerance across latitudes. Science; 348 (6242), 1460, 2015.

76. PALUMBI S.R., BARSHIS D.J., TRAYLOR-KNOWLES N., BAY R.A. Mechanisms of reef coral resistance to future climate change. Science; 344 (6186), 895, 2014.

77. RÄDECKER N., POGOREUTZ C., VOOLSTRA C.R., WIEDENMANN J., WILD C. Nitrogen cycling in corals: the key to understanding holobiont functioning? Trends in Microbiology; 23 (8), 490, 2015.

78. SHARP K., SNEED J., RITCHIE K., MCDANIEL L., PAUL V. Induction of Larval Settlement in the Reef Coral Porites astreoides by a Cultivated Marine Roseobacter Strain. The Biological bulletin; 228, 98, 2015.

79. GÓMEZ-LEMOS L.A., DOROPOULOS C., BAYRAKTAROV E., DIAZ-PULIDO G. Coralline algal metabolites induce settlement and mediate the inductive effect of epiphytic microbes on coral larvae. Scientific Reports; 8 (1), 17557, 2018.

80. AINSWORTH D., TRACY KRAUSE L., BRIDGE T., TORDA G., RAINA J.-B., ZAKRZEWSKI M., et al. The coral core microbiome identifies rare bacterial taxa as ubiquitous endosymbionts. The ISME Journal; 9 (10), 2261, 2015.

81. HERNANDEZ-AGREDA A., GATES R.D., AINSWORTH T.D. Defining the Core Microbiome in Corals' Microbial Soup. Trends in Microbiology; 25 (2), 125, 2017.

82. RÖTHIG T., OCHSENKÜHN M.A., ROIK A., VAN DER MERWE R., VOOLSTRA C.R. Long-term salinity tolerance is accompanied by major restructuring of the coral bacterial microbiome. Molecular Ecology; 25 (6), 1308, 2016.

83. NAKAMURA N., KAYANNE H., TAKAHASHI Y., SUNAMURA M., HOSOI G., YAMANO H. Anthropogenic Anoxic History of the Tuvalu Atoll Recorded as Annual Black Bands in Coral. Scientific Reports; 10 (1), 7338, 2020. 
84. CRUZ D.W.D, HARRISON P.L. Enhanced larval supply and recruitment can replenish reef corals on degraded reefs. Scientific Reports; 7, 13985, 2017.

85. GANN G., MCDONALD T., WALDER B., ARONSON J., NELSON C.R., JONSON J., et al. International principles and standards for the practice of ecological restoration. Second edition ed.; 2019.

86. BOSTRÖM-EINARSSON L., BABCOCK R.C., BAYRAKTAROV E., CECCARELLI D., COOK N., FERSE S.C.A. ea. Coral restoration - A systematic review of current methods, successes, failures and future directions. PLoS ONE; 15 (1), e0226631, 2020.

87. CARNE L., KAUFMAN L., SCAVO LORD K. Measuring success for Caribbean acroporid restoration: key results from ten years of work in southern Belize. 2016.

88. CALLE-TRIVIÑO J., CORTÉS-USECHE C., SELLARES-BLASCO R.I., ARIAS-GONZÁLEZ J.E. Assisted fertilization of threatened Staghorn Coral to complement the restoration of nurseries in Southeastern Dominican Republic. Regional Studies in Marine Science; 18, 129, 2018.

89. LINDEN B. Elaborating an eco-engineering approach for stock enhanced sexually derived coral colonies. Journal of Experimental Marine Biology and Ecology; 486, 2017.

90. KOTB M.M.A. Coral translocation and farming as mitigation and conservation measures for coastal development in the Red Sea: Aqaba case study, Jordan. Environmental earth sciences; 75 (5), 439, 2016.

91. BIRKELAND C. Chapter 2 - Global Status of Coral Reefs: In Combination, Disturbances and Stressors Become Ratchets. In: Sheppard C, editor World Seas: an Environmental Evaluation (Second Edition). Academic Press; 35, 2019.

92. SEMENZA JAN C., TRINANES J., LOHR W., SUDRE B., LÖFDAHL M., MARTINEZ-URTAZA J., et al. Environmental Suitability of Vibrio Infections in a Warming Climate: An Early Warning System. Environmental Health Perspectives; 125 (10), 107004, 2017.

93. EGAN S., GARDINER M. Microbial Dysbiosis: Rethinking Disease in Marine Ecosystems. Frontiers in Microbiology; 7 (991), 2016.

94. WEST A.G., WAITE D.W., DEINES P., BOURNE D.G., DIGBY A., MCKENZIE V.J., et al. The microbiome in threatened species conservation. Biological Conservation; 229, 85, 2019.

95. EPSTEIN H.E., SMITH H.A., TORDA G., VAN OPPEN M.J.H. Microbiome engineering: enhancing climate resilience in corals. Frontiers in Ecology and the Environment; 17 (2), 100, 2019.

96. FRAGOSO ADOS SANTOS H., DUARTE G.A.S., RACHID C.T.D.C., CHALOUB R.M., CALDERON E.N., MARANGONI L.F.D.B., et al. Impact of oil spills on coral reefs can be reduced by bioremediation using probiotic microbiota. Scientific Reports; 5 (1), 18268, 2015.

97. CUNNING R., SILVERSTEIN R.N., BAKER A.C. Investigating the causes and consequences of symbiont shuffling in a multi-partner reef coral symbiosis under environmental change. Proceedings of the Royal Society B: Biological Sciences; 282 (1809), 20141725, 2015.

98. CORNWALL W. The reef builders. Science; 363 (6433), 1264, 2019.

99. PEIXOTO R.S., SWEET M., BOURNE D.G. Customized Medicine for Corals. Frontiers in Marine Science; 6 (686), 2019.
100. ROSADO P.M., LEITE D.C.A., DUARTE G.A.S., CHALOUB R.M., JOSPIN G., NUNES DA ROCHA U., et al. Marine probiotics: increasing coral resistance to bleaching through microbiome manipulation. The ISME Journal; 13 (4), 921, 2019.

101. WOOD T.L., GUHA R., TANG L., GEITNER M., KUMAR M., WOOD T.K. Living biofouling-resistant membranes as a model for the beneficial use of engineered biofilms. Proc Natl Acad Sci USA; 113 (20), E2802-11, 2016.

102. COHEN Y., JOSEPH POLLOCK F., ROSENBERG E., BOURNE D.G. Phage therapy treatment of the coral pathogen Vibrio coralliilyticus. Microbiology Open; 2 (1), 64, 2013.

103. WEBSTER N.S., REUSCH T.B.H. Microbial contributions to the persistence of coral reefs. The ISME Journal; 11 (10), 2167, 2017.

104. TORDA G., DONELSON J.M., ARANDA M., BARSHIS D.J., BAY L., BERUMEN M.L., et al. Rapid adaptive responses to climate change in corals. Nature Climate Change; 7 (9), 627, 2017.

105. HUGHES T.P., BARNES M.L., BELLWOOD D.R., CINNER J.E., CUMMING G.S., JACKSON J.B.C., et al. Coral reefs in the Anthropocene. Nature; 546 (7656), 82, 2017.

106. HUGGETT M.J., APPRILL A. Coral microbiome database: Integration of sequences reveals high diversity and relatedness of coral-associated microbes. Environmental Microbiology Reports; 11 (3), 372, 2019.

107. MAHMOUD HM, KALENDAR AA. CoralAssociated Actinobacteria: Diversity, Abundance, and Biotechnological Potentials. Frontiers in Microbiology; 7 (204), 2016

108. ZANEVELD J.R., BURKEPILE D.E., SHANTZ A.A., PRITCHARD C.E., MCMINDS R., PAYET J.P., et al. Overfishing and nutrient pollution interact with temperature to disrupt coral reefs down to microbial scales. Nature Communications; 7 (1), 11833, 2016.

109. RUSCH A., HANNIDES A., GAIDOS E.J. Diverse communities of active Bacteria and Archaea along oxygen gradients in coral reef sediments. Coral Reefs; 28, 15, 2009.

110. DANIELS C., BAUMGARTEN S., YUM L., MICHELL C., BAYER T., ARIF C., RODER C., WEIL E., VOOLSTRA C. Metatranscriptome analysis of the reefbuilding coral Orbicella faveolata indicates holobiont response to coral disease. Frontiers in Marine Science. 2, 2015.

111. BLACKALL L.L W.B., AND VAN OPPEN MJH. 2015. CORAL - THE WORLD'S , MOST DIVERSE SYMBIOTIC ECOSYSTEM. MOL ECOL 24: 5330-47. DANIELS C., BAUMGARTEN S., YUM L., MICHELL C., BAYER T., ARIF C., RODER C., WEIL E., VOOLSTRA C. Metatranscriptome analysis of the reefbuilding coral Orbicella faveolata indicates holobiont response to coral disease. Frontiers in Marine Science. 2, 2015.

112. GAIDOS E., RUSCH A., ILARDO M. Ribosomal tag pyrosequencing of DNA and RNA from benthic coral reef microbiota: community spatial structure, rare members and nitrogen-cycling guilds. Environmental Microbiology; 13 (5), 1138, 2011.

113. WEINBAUER M., KERROS M.-E., MOTEGI C., WILHARTITZ I., RASSOULZADEGAN F., TORRÉTON J.-P., et al. Bacterial community 
composition and potential controlling mechanisms along a trophic gradient in a barrier reef system. Endangered Species Research; 11, 2010.

114. NELSON C.E., ALLDREDGE A.L., MCCLIMENT E.A., AMARAL-ZETTLER L.A., CARLSON C.A. Depleted dissolved organic carbon and distinct bacterial communities in the water column of a rapid-flushing coral reef ecosystem. Isme j; 5 (8), 1374, 2011.

115. MHUANTONG W., NURYADI H., TRIANTO A., SABDONO A., TANGPHATSORNRUANG S., EURWILAICHITR L., et al. Comparative analysis of bacterial communities associated with healthy and diseased corals in the Indonesian sea. PeerJ; 7, e8137, 2019.

116. BADHAI J., GHOSH T.S., DAS S.K. Composition and Functional Characterization of Microbiome Associated with Mucus of the Coral Fungia echinata Collected from Andaman Sea. Front Microbiol; 7, 936, 2016.

117. LIMA L.F.O., WEISSMAN M., REED M., PAPUDESHI B., ALKER A.T., MORRIS M.M., et al. Modeling of the
Coral Microbiome: the Influence of Temperature and Microbial Network. mBio; 11 (2), 2020.

118. WEIL E., ROGERS C. Coral reef diseases in the AtlanticCaribbean. In: Zvy Dubinsky NS, editor Coral Reefs: An Ecosystem in Transition.; 465, 2011.

119. RITCHIE K., SMITH G. Preferential carbon utilization by surface bacterial communities from water mass, normal, and white-band diseased Acropora cervicornis. Molecular marine biology and biotechnology; 4, 345, 1995.

120. KUSHMARO A., BANIN E., LOYA Y., STACKEBRANDT E., ROSENBERG E. Vibrio shiloi sp. nov., the causative agent of bleaching of the coral Oculina patagonica. Int J Syst Evol Microbiol; 51 (Pt 4), 1383, 2001.

121. KIM K., RYPIEN K. Aspergillosis of Caribbean Sea Fan Corals, Gorgonia spp., 236, 2015. 